\section{Polri Performance: The Relationship to Achievement Motivation and The Working Environment}

\author{
Hari Slamet Trianto, Christiana Hari \\ Soetjiningsih, Adi Setiawan
}

Journal PSIKODIMENSIA

Volume 19, No. 2,

Juli - Desember 2020

ISSN cetak : 1411-6073

ISSN online : 2579-6321

DOI:10.24167/psidim.v19i2.2682

Magister Psikologi, Fakultas Psikologi, Universitas
Kristen Satya Wacana, Salatiga
email : hastri.1436@gmail.com,
soetji_25@yahoo.co.id, adi_setia_03@yahoo.com

Abstract

The purpose of this study is examining the effect of achievement motivation and work environment simultaneously on the performance of Police Officers. This research is a type of quantitative research. The participants in this study were 100 police officers in Salatiga with saturation sampling technique. The instrument used was Achievement Motivation Scale, Work Environtment Scale, and Performance Scale.Data analysis technique used multiple liniar regression. The results showed that achievement motivation and work environment proved to simultaneously have a significant effect on the performance of police officers with contribution value of $28.50 \%$. This shows that the higher the achievement motivation and the better the work environment, the higher of performance of Police Officers. Achievement motivation and work environment as predictor the performance of police officers.

Keywords: Achievement Motivation, Work Environment, Performance, Police Officers.

\section{PENDAHULUAN}

Reformasi Birokrasi yang dilaksanakan di tubuh Polri selama ini secara umum sudah menunjukkan berbagai perubahan positif, namun masih perlu peningkatan agar hasil optimal terutama berkaitan dengan kinerja anggota Polri. Kinerja yang baik merupakan aspek penting dalam upaya pencapaian suatu tujuan, karena kegagalan dalam mencapai sasaran yang telah dirumuskan merupakan akibat dari kinerja individu atau tim yang tidak optimal.

$$
\text { Dari Survey Kepuasan }
$$

Masyarakat (SKM) tahun 2019 yang dilakukan oleh pihak Polri yaitu Polres Salatiga dengan melibatkan masyarakat sebagai responden, diperoleh hasil penilaian masyarakat yang masih kurang puas dengan kinerja anggota Polri. Hal tersebut dapat dilihat dari beberapa hasil penilaian masyarakat terhadap anggota Polri antara lain: 1) cepat merasa puas, 2) kurang kreatif dan inovatif, 3) kurang mampu memperbaiki diri, 4) tidak mampu berkompetisi secara bebas dan sehat, 5) kurang gemar membaca dan menulis, 6) membenarkan yang biasa tidak membiasakan yang benar, 7) senang melihat orang lain susah dan susah melihat orang lain senang, 8) senang dibelaskasihani dan bangga dapat gratis, 9) tidak konsekuen dan tidak konsisten, 10) bersifat ganda atau ambivalen. Hasil SKM tersebut sejalan dengan hasil wawancara yang dilakukan oleh penulis dengan beberapa orang masyarakat yang melakukan pelaporan di Polres Salatiga. Sebagian besar jawaban menyatakan bahwa anggota Kepolisian Polres Salatiga belum dapat tepat waktu dalam melakukan 
penanganan laporan masyarakat, belum mampu menangani setiap pengaduan masyarakat secara akurat, belum memiliki kemauan untuk membantu segera setiap laporan kriminal yang diadukan oleh masyarakat, dan belum bersedia menyampaikan informasi secara baik dan jelas terhadap setiap permasalahan yang dihadapi oleh masyarakat. Kondisi tersebut memberikan gambaran bahwa kinerja anggota Polri Polres Salatiga masih dinilai kurang sesuai dengan harapan. Dengan kondisi yang demikian, perlu dilakukan upaya peningkatan kinerja anggota yang diawali dengan mengetahui faktor-faktor yang memengaruhi kinerja yang kurang memuaskan pada anggota Polri Polres Salatiga.

Menurut Mangkunegara (2009), kinerja karyawan adalah hasil kerja secara kualitas dan kuantitas yang dicapai oleh seseorang karyawan dalam melaksanakan tugasnya sesuai dengan tanggung jawab yang diberikan kepadanya. Kinerja dapat diungkap melalui penilaian kinerja yang mencakup 5 aspek yaitu prestasi kerja, kejujuran, kedisiplinan, prakarsa, dan kepribadian. Menurut Dharma (2006), faktor-faktor yang memengaruhi kinerja yaitu berkaitan dengan 1).Pegawai, mencakup kapasitas kemampuan dan kemauan dalam melaksanakan pekerjaan (motivasi berprestasi), 2) Pekerjaan, menyangkut desain pekerjaan, uraian pekerjaan dan sumber daya untuk melaksanakan pekerjaan, 3) Mekanisme kerja, mencakup system, prosedur pendelegasian dan pengendalian, dan 4) Lingkungan kerja, meliputi faktor-faktor lokasi dan kondisi kerja, iklim organisasi dan komunikasi.

Hasil pengamatan dan wawancara yang dilakukan oleh penulis selama ini di Polres Salatiga menunjukkan bahwa salah satu faktor yang memengaruhi kinerja adalah motivasi berprestasi. Terdapat sebagian anggota yang menunjukan motivasi berprestasi rendah, nampak dari beberapa anggota pernah terkana kasus sehingga kenaikan pangkatnya ditunda, pada umumnya mereka tidak bersedia untuk mengembangkan dirinya seperti halnya melanjutkan studi ke jenjang yang lebih tinggi. Padahal dengan mengikuti studi akan mempercepat kenaikan pangkat, selain itu mereka pada umumnya bersikap apatis (kurang greget).

Selain dipengaruhi oleh motivasi berprestasi, menurut hasil pengamatan penulis lingkungan kerja yang kurang mendukung juga menjadi salah satu penyebab kurang optimalnya kinerja anggota. Kurang nyamannya lingkungan kerja di Polres Salatiga dapat dilihat dari beberapa aspek, seperti: fasilitas kerja yang kurang memadai (jumlah komputer kurang dan pengadaan dari pusat juga tidak dapat diandalkan sehingga anggota harus swadaya untuk pengadaan fasilitas tersebut), tata ruang antar bagian yang tidak ada sekatnya sehingga terkesan tidak ada jaminan privasi dalam kantor, luas kantor dengan jumlah anggota yang bekerja didalamnya tidak berimbang, ruang kantor yang berdebu karena sering rontoknya tembok gedung karena usia gedung yang sudah tua, hubungan antara pimpinan dan beberapa orang anggota kurang harmonis, dan hubungan antara beberapa sesama anggota kurang harmonis. Hasil pengamatan penulis tersebut juga sesuai dengan hasil wawancara terhadap 10 orang masyarakat pelapor di Polres Salatiga, yang semuanya menyatakan "tidak setuju" untuk pertanyaan bahwa 1) menurut masyarakat kantor yang ditempati oleh anggota Polres Salatiga secara umum telah memenuhi standar keamanan dan kenyamanan bagi setiap masyarakat pelapor, 2) Kantor Polres Salatiga memiliki kelengkapan fasilitas fisik yang baik, sehingga setiap pelayanan yang dilakukan terhadap masyarakat dapat terdata secara baik dan akurat.

Motivasi berprestasi merupakan daya penggerak yang membuat seorang 
semangat bekerja, mendorong seseorang untuk mengembangkan kreativitas, dan menggerakkan semua kemampuan serta energi yang dimilikinya demi mencapai prestasi kerja (kinerja) yang maksimal (McClelland, 1987 dalam Djiwandono, 2002). Pernyataan tersebut sejalan dengan pendapat Rivai (2004), bahwa semakin kuat motivasi berprestasi, kinerja pegawai akan semakin tinggi, demikian pula sebaliknya. Dharma (2006) juga berpendapat sama, bahwa salah satu faktor yang mempengaruhi kinerja adalah motivasi pegawai itu sendiri, berkenaan dengan kapasitas kemampuan dan kemauan dalam melaksanakan pekerjaan. Demikian pula menurut Syafaruddin (2002), seseorang yang mempunyai motivasi yang tinggi maka dia akan berusaha melakukan yang terbaik, memiliki kepercayaan terhadap kemampuan untuk bekerja mandiri dan bersikap optimis, memiliki ketidakpuasan terhadap prestasi yang telah diperoleh serta mempunyai tanggung jawab yang besar atas perbuatan yang dilakukan sehingga seseorang yang mempunyai motivasi berprestasi yang tinggi pada umumnya lebih berhasil dalam menjalankan tugas dibandingkan dengan mereka yang memiliki motif berprestasi yang rendah. McClelland (dalam Djiwandono, 2002), menyatakan bahwa individu yang memiliki motivasi berprestasi tinggi memiliki karakteristik bertanggung jawab, memanfaatkan umpan balik, inovatif, dan sukses dalam pekerjaan.

Menurut pendapat Sedarmayati (2001) dan Dharma (2006), lingkungan kerja merupakan salah satu faktor yang ikut berperan dalam mempengaruji kinerja karyawan/pegawai. Pendapat tersebut sejalan dengan kajian yang dilakukan oleh Jordan, Ashkanasy, dan Hartel (2002), Hofmann dan Jones (2005), bahwa kinerja pegawai dipengaruhi oleh dua faktor yaitu faktor eksternal dan faktor internal. Faktor eksternal dalam hal ini salah satunya merujuk pada lingkungan kerja. Kajian tersebut juga diperkuat oleh beberapa peneliti, seperti: Sirgy, Efraty, Siegel, dan Lee (2001) yang mengikut sertakan lingkungan kerja sebagai salah satu indikator dalam mengukur QWL (Quality of Work Life) karyawan. Lingkungan kerja mencakup lingkungan kerja fisik dan non fisik (Sedarmayati, 2001). Sedarmayanti (2001) menyatakan bahwa secara garis besar, jenis lingkungan kerja terbagi menjadi 2 (dua), yakni: lingkungan kerja fisik, dan lingkungan kerja non fisik. Lingkungan kerja fisik dapat dibagi dalam 2 (dua) kategori, yakni a) Lingkungan yang langsung berhubungan dengan karyawan (seperti: pusat kerja, kursi, meja, fasilitas kerja dan sebagainya)., b) Lingkungan perantara atau lingkungan umum dapat juga disebut lingkungan kerja yang mempengaruhi kondisi manusia, misalnya: temperatur, kebersihan, kelembaban, sirkulasi udara, pencahayaan, kebisingan, getaran mekanis, bau tidak sedap, warna, dan lain-lain. Lingkungan non fisik berkaitan dengan hubungan kerja, baik hubungan dengan atasan maupun hubungan sesama rekan kerja, ataupun hubungan dengan bawahan. Menurut Sadarmayanti (2001), lingkungan kerja non fisik adalah semua keadaan yang terjadi yang berkaitan dengan hubungan kerja, baik hubungan dengan atasan maupun hubungan sesama rekan kerja, ataupun hubungan dengan bawahan. Lingkungan non fisik ini juga merupakan kelompok lingkungan kerja yang tidak bisa diabaikan. Hal yang sama juga diungkapkan oleh Moekijat (2009) bahwa lingkungan kerja non fisik meliputi: hubungan-hubungan orang lain dalam organisasi, dan komunikasi. Menurut Anoraga (2001), lingkungan kerja yang baik akan membawa pengaruh yang baik kepada para karyawan, pimpinan, dan hasil pekerjaannya. Ditambahkan pula oleh As'ad (2001), bahwa rasa aman akan suasana kerja yang mampu mendorong karyawan untuk lebih berdedikasi tinggi 
dalam menyelesaikan tugas yang diberikan oleh pimpinan baik suasana aman sebelum kerja, saat kerja maupun setelah kerja. Kondisi kerja yang aman semacam ini, serta didukung rekan kerja yang dapat diajak untuk bekerjasama dalam berbagai aktifitas merupakan keinginan dari setiap pegawai administrasi di suatu instansi/organisasi.

Berdasarkan uraian yang telah dipaparkan, penulis menduga bahwa motivasi berprestasi dan lingkungan kerja merupakan faktor-faktor yang memengaruhi kinerja anggota Polri Polres Salatiga. Motivasi berprestasi yang tinggi dan lingkungan kerja yang baik secara bersama (simultan) meningkatkan kinerja, dan sebaliknya. Dari penelusuran penulis pada beberapa jurnal belum banyak penelitian yang menguji tentang pengaruh motivasi berprestasi dan lingkungan kerja secara simultan terhadap kinerja. Yang banyak adalah penelitian yang parsial, yaitu penelitian tentang pengaruh motivasi berprestasi terhadap kinerja (Saripuddin, 2012; Wardana, 2013; Misnawati, 2015), dan pengaruh lingkungan kerja terhadap kinerja (Widyasworo, 2014; Cahyono, 2015; Wijaya, 2017; Sriharmiyati,
2018). Oleh karena itudalam peneltian ini penulis ingin menguji motivasi berprestasi dan lingkungan kerja secara simultan sebagai prediktor kinerja anggota Polri. Hipotesis penelitian ini yaitu motivasi berprestasi dan lingkungan kerja secara simultan sebagai prediktor kinerja.

\section{METODE}

Penelitian ini merupakan
penelitian kuantitatif. independen yaitu motivasi berprestasi dan lingkungan kerja, serta variabel dependen yaitu kinerja. Partisipan penelitian adalah 100 orang Anggota Polri Polres Salatiga yang diperoleh dengan menggunakan teknik sampling jenuh. Berdasarkan tahun kelulusan dan Dik Polri serta lama masa kerja terdiri dari: 10 orang kelulusan Dik Polri tahun 1980-1989 (masa dinas $\geq 30$ tahun), 30 orang kelulusan Dik Polri tahun 19901999 (masa dinas 20-29 tahun), 30 orang kelulusan Dik Polri tahun 2000-2009 (masa dinas 10-19 tahun), dan 30 orang ari kelulusan Dik Polri tahun 2010-2019 (masa dinas 1-9 tahun). Karakteristik partisipan selengkapnya sebagai berikut:

Tabel Karakteristik Responden

\begin{tabular}{|c|c|c|c|c|c|}
\hline No & \multicolumn{2}{|c|}{ Keterangan } & Jumlah & Presentase & Responden \\
\hline \multirow[t]{2}{*}{1} & Jenis Kelamin & Laki-laki & 70 & 70,00 & 100 \\
\hline & & Perempuan & 30 & 30,00 & \\
\hline \multirow[t]{4}{*}{2} & Umur & $18-29$ & 30 & 30,00 & 100 \\
\hline & & $30-39$ & 30 & 30,00 & \\
\hline & & $40-48$ & 30 & 30,00 & \\
\hline & & $50-57$ & 10 & 10,00 & \\
\hline \multirow[t]{3}{*}{3} & Pendidikan & SMA & 60 & 60,00 & 100 \\
\hline & & Sarjana & 35 & 35,00 & \\
\hline & & Pasca Sarjana & 5 & 5,00 & \\
\hline \multirow[t]{4}{*}{4} & Lama Bekerja & 1-9 tahun & 30 & 30,00 & 100 \\
\hline & & 10-19 tahun & 30 & 30,00 & \\
\hline & & 20-29 tahun & 30 & 30,00 & \\
\hline & & $\geq 30$ tahun & 10 & 10,00 & \\
\hline
\end{tabular}

Sumber: Data Primer Diolah, 2019 
diungkap dengan menggunakan 3 skala psikologis yang disusun oleh penulis yaitu: 1). Skala Kinerja, berdasarkan aspek-aspek penilaian kinerja menurut Mangkunegara (2009), yaitu prestasi kerja, kejujuran, kedisiplinan, prakarsa, kepribadian; 2). Skala Motivasi Berprestasi berdasarkan aspek-aspek motivasi berprestasi menurut McClelland (dalam Djiwandono (2002), yaitu: bertanggung jawab, memanfaatkan umpan balik, inovatif, sukses dalam pekerjaan; 3) Skala Lingkungan Kerja, berdasarkan aspekaspek penerangan/cahaya, kebersihan, temperatur dan kelembaban, sirkulasi udara, kebisingan, bau-bauan, dekorasi, keamanan, suasana kekeluargaam, komunikasi yang baik, pengendalian diri. Sebelum digunakan dilakukan uji coba dengan menggunakan subjek- 50 orang. Untuk uji seleksi aitem menggunakan uji daya diskriminasi dengan syarat $\mathrm{r}$ item-total minimal $\geq$ 0,30) dan uji reliabilitas dengan Alpha Cronbach. Hasil uji menunjukkan bahwa 24 aitem Skala Kinerja memiliki daya diskriminasi yang baik ( $\mathrm{r}$ it berkisar 0,40 $\mathrm{s} / \mathrm{d} 0,85 \geq 0,30$ ), begitu juga 20 aitem pada Skala motivasi berprestasi ( $\mathrm{r}$ it 0,36 s/d 0,80). Sementara untuk Skala lingkungan kerja ada 1 aitem yang gugur sehingga aitem yang baik berjumlah 27 aitem. Hasil uji reliabilitas diperoleh nilai Cronbach alpha untuk variabel motivasi berprestasi $(\mathrm{X} 1)=0,96$, lingkungan kerja $(\mathrm{X} 2)=0,90$, dan kinerja anggota $(Y)=0,96$; dengan demikian ketiga skala realibel dan layak digunakan.

\section{HASIL}

Sebelum uji hipotesis dilakukan uji asumsi terlebih dahulu dan semua uji memenuhi syarat 1). Uji normalitas menunjukkan bahwa sebaran data residual semua variabel berdistribusi normal karena nilai KSZ sebesar 0,756 dengan nilai signifikansi 0,617 ( $p>0,05)$. 2) Uji linearitas dengan analisis varians antara lingkungan kerja dan kinerja menunjukkan bahwa $F=32,273$ dan nilai signifikansi $0,000(\mathrm{p}<0,05)$ serta antara motivasi berprestasi dengan kinerja menunjukkan $\mathrm{F}=29,580$ dan nilai signifikansi $0,000(\mathrm{p}<0,05)$, yang bermakna hubungan variabel-variabel tersebut linier. 3). Uji multikolinieritas menunjukkan bahwa nilai tolerance untuk variabel motivasi berprestasi (X1) $=0,767$, dan lingkungan kerja $(\mathrm{X} 2)=$ 0,767 , sedang nilai VIF (Variance Inflation Factor) untuk variabel variabel motivasi berprestasi $(\mathrm{X} 1)=1,303$ dan lingkungan kerja $(X 2)=1,303$. Sesuai dengan kriteria yang ditetapkan maka tidak terdapat multikolinieritas.4). Uji heterokedastisitas menunjukkan titiktitik menyebar dan tidak membentuk pola yang jelas sehingga dapat disimpulkan bahwa tidak terjadi heterokedastisitas.

Uji hipotesis dengan analisis regresi berganda menunjukkan bahwa $\mathrm{F}$ $=19,355$ dan nilai signifikansi 0,000 $(\mathrm{p}<0,05)$ yang berarti ada pengaruh motivasi berprestasi dan lingkungan kerja secara simultan terhadap kinerja Anggota Polri. Ini bermakna motivasi berprestasi dan lingkungan kerja secara simultan sebagai prediktor kinerja Anggota Polri. Besarnya nilai R Square adalah 0,285 yang berarti $28,50 \%$ varians kinerja anggota dapat dijelaskan oleh motivasi berprestasi dan lingkungan kerja, dan sebesar $71,50 \%$ dipengaruhi oleh variabel-variabel lain. Selanjutnya nilai koefisien regresi variabel motivasi berprestasi (b1) adalah sebesar 0,368, dan lingkungan kerja (b2) adalah sebesar 0,427 , maka persamaan regresinya dapat dijabarkan $Y=0,368 X 1+0,427 X 2$. Juga dapat dikemukakan, bahwa lingkungan kerja memiliki pengaruh yang lebih besar terhadap kinerja anggota dibanding variabel motivasi berprestasi, dan secara parsial baik lingkungan kerja maupun motivasi berprestasi berpengaruh signifikan terhadp kinerja 
DISKUSI

Hasil penelitian menunjukkan bahwa motivasi berprestasi dan lingkungan kerja secara simultan berpengaruh signifikan terhadap kinerja anggota, yang bermakna motivasi berprestasi dan lingkungan kerja secara simultan sebagai predictor kinerja anggota. Semakin tinggi motivasi berprestasi anggota dan semakin baik lingkungan kerja, maka akan meningkatkan kinerja anggota, begitu pula sebaliknya. Temuan hasil penelitian ini sejalan dengan pernyataan yang dikemukakan oleh McClelland (dalam Djiwandono (2002), bahwa motivasi berprestasi merupakan daya penggerak yang memotivasi semangat bekerja seseorang, yang mendorong seseorang untuk mengembangkan kreativitas dan menggerakkan semua kemampuan serta energi yang dimilikinya demi mencapai prestasi kerja (kinerja) yang maksimal. Pendapat tersebut juga sejalan dengan Anoraga (2001), bahwa lingkungan kerja yang baik akan membawa pengaruh yang baik kepada hasil pekerjaan karyawan (kinerja karyawan), juga mendukung pendapat Dharma (2006), bahwa salah satu faktor yang mempengaruhi kinerja pegawai adalah lingkungan kerja. Hasil juga sesuai dengan pendapat Sedarmayati (2001), dimana lingkungan kerja dalam organisasi (swasta ataupun pemerintah) sangat penting untuk mendapat perhatian. Lingkungan kerja yang memusatkan bagi karyawannya dapat meningkatkan kinerja, sebaliknya lingkungan kerja yang tidak memadai dapat menurunkan kinerja. Notoatmodjo (2009) juga berpendapat sama, dimana lingkungan kerja yang tidak kondusif, sering atau bahkan selalu menghambat kinerja karyawan (pegawai). Kajian penelitian yang dilakukan oleh Widyasworo (2014), Cahyono (2015), dan Wijaya (2017), serta Sriharmiyati (2018) juga membuktikan bahwa lingkungan kerja berpengaruh signifikan terhadap kinerja karyawan
Dengan memiliki motivasi berprestasi, maka anggota Polri siap menerima resiko apapun terhadap keputusan yang diambil dalam pekerjaan, antusias menyelesaikan pekerjaan yang sesuai job deskripsi, menghendaki segera mendapat umpan balik hasil pekerjaan dari rekan/atasan, tidak terlena dengan pujian terhadap hasil kerja dari rekan/atasan, tetap semangat apabila hasil pekerjaan dinilai kurang sesuai oleh rekan/atasan, suka mencari informasi-informasi baru dari berbagai sumber yang sekiranya dapat meningkatkan prestasi kerjanya, memiliki pandangan jauh ke depan, sehingga sering bertanya-tanya bagaimana cara memperbaiki sesuatu hal. Selain itu, Anggota Polri juga akan suka melakukan hal-hal yang baru terkait dengan pekerjaan, mampu mengeluarkan ide orisinil dalam menyelesaikan setiap permasalahan dalam pekerjaan, mampu menemukan pendekatan baru dalam melaksanakan tugas pekerjaan, mampu membuat atasan untuk bersikap antusias terhadap gagasan inovatif yang dikeluarkan, mampu menyakinkan rekan/pimpinan untuk mendukung gagasan inovatif yang dikeluarkan, secara sistematis dapat mengenalkan gagasan inovatif ke dalam praktek kerja, berkontribusi dalam penerapan gagasan baru, berusaha menempatkan diri dalam hal pengembangan hal baru, hasil kerja selalu mendapat apresiasi dari rekan/atasan, memiliki kondite kerja yang baik, job deskripsi pekerjaan yang menantang memacu diri pribadi untuk menunjukkan prestasi kerja yang lebih baik, tetap bekerja dengan baik walaupun tugas pekerjaan yang dilakukan sulit, bersikap optimis dalam menghadapi setiap permasalahan pekerjaan. Kondisi motivasi berprestasi anggota tersebut pada akhirnya mendorong anggota untuk menampilkan kinerja secara baik.

Apabila anggota memiliki motivasi berprestasi yang tinggi dan 
didukung lingkungan kerja (fisik dan non fisik) yang baik akan berefek pada kinerja yang tinggi. Dengan lingkungan kerja fisik yang memadai seperti kebersihan ruang kerja, ruang kerja yang harum dan wangi, penataan ruang kerja, penerangan yang baik di ruang kerja, temperatur dan kelembaban ruang kerja yang terjaga baik, sirkulasi udara yang baik, suasana kerja yang jauh dari kebisingan, dan suasana yang jauh dari kebisingan, dan fasilitas kerja, seperti: jumlah dan kualitas komputer yang memadai (dinilai dengan kategori cukup atau kurang sesuai dengan harapan) akan memberi efek kenyamanan dan keyakinan bahwa tugas-tugas dapat diselesaikan dengan baik. Disisi lain lingkungan non fisik seperti suasana kekeluargaan, komunikasi yang disampaikan oleh atasan mudah diterima, komunikasi yang disampaikan oleh atasan tidak menimbulkan keraguan bagi anggota sebagai bawahan, atasan selalu memberikan informasi pekerjaan tepat waktu, atasan mampu mempertanggung jawabkan segala sesuatu yang diinformasikan kepada anggota, atasan selalu memanggil anggota secara pribadi jika hal yang disampaikan memang sifatnya individual, dan tumbuhnya kesadaran dalam hal pengendalian diri setiap anggota; akan berefek pada munculnya perasaan dihargai, dipedulikan, dan dibutuhkan yang akan mendorong anggota melaksanakan tugas-tugasnya dengan baik.

Penataan lingkungan kerja dengan tata warna yang sesuai sangat penting, karena menurut Sedarmayati (2001) menjelaskan bahwa pada kenyataannya tata warna tidak dapat dipisahkan dengan penataan dekorasi. Hal ini dapat dipahami karena warna mempunyai pengaruh besar terhadap perasaan seperti rasa senang, sedih, dan lain-lain. Moekijat (2009) juga menyatakan hal yang sama, bahwa warna biasanya juga mempunyai pengaruh yang penting atas tekanan darah dan ketegangan syaraf.
Kemudian kondisi bangunan ruang kerja yang kuat dan kokoh, berkaitan dengan keamanan kerja (Sedarmayati, 2001). Keamanan kerja mempunyai pengaruh terhadap ketenangan karyawan dalam bekerja, selain usaha untuk menyelesaikan tugas-tugas yang dibebankan dengan baik dan penuh tanggung jawab. Ditambahkan oleh As'ad (2001), bahwa rasa aman akan suasana kerja mampu mendorong karyawan untuk lebih berdedikasi tinggi dalam menyelesaikan tugas yang diberikan oleh pimpinan baik suasana aman sebelum kerja, saat kerja maupun setelah kerja. Berkaitan dengan fasilitas kerja, menurut Gillmer dalam As'ad (2001) fasilitas yang diterima dari perusahaan dan langsung dinikmati akan menimbulkan rasa puas bagi karyawan. Hal yang sama juga dikemukan oleh As'ad (2001), bahwa faktor fisik yang salah satunya berupa perlengkapan kerja merupakan salah satu faktor yang mempengaruhi kepuasan kerja karyawan. Kepuasan kerja akan berefek pada kinerja yang baik.

Temuan lain hasil penelitian ini juga menunjukkan, bahwa motivasi berprestasi dan lingkungan kerja memberikan kontribusi sebesar 28,50\% terhadap kinerja anggota. Temuan tersebut mendukung pendapat Dharma (2006), dan Astuti, Rokhmat, dan Sudirman (2017), bahwa faktor motivasi berprestasi dan lingkungan kerja merupakan beberapa faktor yang mempengaruhi kinerja.

\section{SIMPULAN}

Hasil penelitian menunjukkan bahwa motivasi berprestasi dan lingkungan kerja secara simutan berpengaruh signifikan terhadap kinerja Anggota Polri. Motivasi berprestasi dan lingkungan kerja secara simutan sebagai prediktor kinerja. Semakin tinggi motivasi berprestasi dan semakin baik lingkungan kerja maka kinerja anggota Polri juga akan meningkat. 
Saran. Agar kinerja anggota lebih optimal maka ada baiknya pihak pimpinan dan segenap jajaran pemegang kebijakan di Polres Salatiga mengambil langkah-langkah kebijakan untuk meningkatkan motivasi berprestasi dan memperbaiki kondisi lingkungan kerja. Kondisi tersebut dapat dilakukan dengan secara aktif melakukan pengajuan anggaran ke Pimpinan Polri tingkat Daerah maupun Pusat, atau melakukan terobosan-terobosan lain misal dengan bekerja sama dengan pemerintah daerah terkait peningkatan kebutuhan dana, misal: untuk kebutuhan pengadaan komputer yang dinilai masih kurang sesuai, atau perbaikan beberapa gedung yang dinilai sudah tidak layak untuk ditempati. Langkah tersebut penting untuk dicoba mengingat lembaga kepolisan adalah lembaga publik yang vital keberadaannya sehingga perlu mendapatkan perhatian yang lebih dari pemerintah daerah.

Pihak penentu kebijakan di Polres Salatiga dapat mempercepat proses program perubahan yang dikemas dalam Grand Strategi Polri tahun 2005-2025 sekaligus dalam rangka pencapaian pelaksanaan Reformasi Birokrasi yang menganut paradigma baru menuju masyarakat madani yang menjunjung tinggi Supremasi Hukum, Moral dan Etika, Demokratisasi, Hak Asasi Manusia, Transparansi Good Governance dan Clean Governance, misal dalam Reformasi Birokrasi Gelombang III, yakni: 1) Program Revolusi Mental Aparatur, 2) Program Penguatan Sistem Pengawasan, 3) Program Penguatan Akuntabilitas Kinerja, 4) Program Penguatan Kelembagaan, 5) Program Penguatan Tatalaksana, 6) Program Penguatan Sistem Manajemen Sumber Daya Manusia, 7) Program Penguatan Peraturan Perundang-Undangan, 8) Program Peningkatan Kualitas Pelayanan Publik, 9) Program Monitoring dan Evaluasi.

\section{DAFTAR PUSTAKA}

Anoraga, P., \& Suyatni, S. (2001). Psikolog industri dan sosial. Jakarta: PT. Dunia Pustaka Jaya.

As'ad, M. (2001). Seri ilmu sumber daya manusia. Yogyakarta: Liberty.

Astuti, Helmi, Rokhmat, Joni, \& Sudirman. (2017). Pengaruh lingkungan kerja dan motivasi berprestasi terhadap kinerja guru Madrasah Ibtidaiyah di Kecamatan Aikmel Kabupaten Lombok Timur. Jurnal Ilmiah Profesi Pendidikan, 2 (1), 112135.

Cahyono, Eko B. 2015. Pengaruh Lingkungan Kerja Terhadap Kinerja Karyawan Pada Industri Kecil Kerajinan Batik Sidomukti Desa Sidomukti Kecamatan Plaosan Kabupaten Magetan. Equilibrium, Volume 3, Nomor 2 (Juli 2015), 144-153.

Cummings, T.G. and E.S. Malloy: 1977, Improving Productivity and the Quality of Work Life (Praeger, New York).

Dharma, Agus. 2006. Manajemen Prestasi Kerja. Jakarta: Rajawali Pers.

Djiwandono. 2002. Pentingnya Motivasi Belajar. Jakarta: Raja Grafindo.

Ghozali, Imam, 2004. Analisis Multivariate Dengan Program SPSS. Semarang: Badan Penerbit Universitas Diponegoro.

Hofmann, D. A. \& Jones, L. M. 2005. Leadership, collective personality, and performance. Journal of Applied Psychology, 3(90), 509522. 
Jordan, P. J., Ashkanasy, N. M., \& Hartel, C. E. J. 2002. Emotional intelligence as a moderator of emotional and behavioral reaktions to job insecurity. Academy of Management Review, 3(27), 361-372.

Kahn, R.: 1981, Work and Health (Wiley, New York)

Lawler, E.E., III.: 1986, 'Strategies for improving the quality of work life', American Psychologist 37, pp. $486-493$

Moekijat, 2009. Tata Laksana Kantor. Bandung: Mandar Maju.

Nitisemito, Alex S., 2000. Manajemen Personalia: Manajemen Sumber Daya Manusia. Jakarta: Ghalia Indonesia.

Riduwan, 2003. Skala Pengukuran Variabel-Variabel Penelitian. AlfaBeta, Bandung.

Rivai, Veithzal. 2004. Manajemen Sumber Daya Manusia Untuk Perusahaan. Jakarta: PT Raja Grafindo Persada.

Sedarmayanti, 2001. Sumber Daya Manusia dan Produktivitas Kerja. Bandung: Mandar Maju.

Sheppard, H.L. and N.O. Herrick: 1972, Where Have All the Robots Gone? Worker Dissatisfaction in the 70's (The Free Press, New York).
Sirgy, M. J., Efraty, D., Siegel, P. \& Lee, D. J. (2001). A new measure of quality of work life ( $Q W L)$ based on need satisfaction and spillover theories. Social Indicators Research, 55(3), 241302.

Sriharmiyati, Leni. 2018. Pengaruh Lingkungan Kerja Terhadap Kinerja Pegawai Kecamatan Magelang Utara. Jurnal Mahasiswa Administrasi Negara (JMAN), ISSN: 2222-3333, Vol. 02 No. 02 (Oktober 2018), 1-9.

Syafaruddin, 2002. Manajemen Mutu Terpadu dalam Pendidikan (Konsep, Strategi, dan Aplikasi). Jakarta: PT Grasindo.

Wijaya, Hendry. 2017. Pengaruh Lingkungan Kerja Terhadap Kinerja Pegawai Pada Instansi Pemerintah Daerah Kabupaten Musi Banyuasin (Studi Kasus Dinas Pertambangan dan Energi Kabupaten Musi Banyuasin). Jurnal Ecoment Global, ISSN: 2540-816X, Volume 2 Nomor 1 (Edisi Februari 2017), 40-50. 